Postgrad. Med. J., 37, 96

\title{
THE VALUE OF BUCCAL STREPTOKINASE/STREPTODORNASE (VARIDASE) IN THE TREATMENT OF MINOR INJURIES
}

\author{
M. C. T. MORRISON, M.B., B.S. \\ Casualty Registrar \\ J. P. G. WILliams, M.R.C.S., L.R.C.P., D.R.C.O.G. \\ Accident Officer
}

The Middlesex Hospital, London, W.I

STREPTOKINASE/STREPTODORNASE has been used for some time as a local application to assist dissolution of slough and fibrin. Now a tablet form-Varidase Buccal (Lederle)-has been produced which the makers claim is effective in reducing traumatic œdema and bruising when absorbed via the buccal mucosa.

The object of this trial was to prove or disprove its value in treating minor injuries.

\section{Material}

The patients were all seen in the Casualty Department of the Middlesex Hospital. They were divided into two groups: (1) Closed soft tissue injuries, i.e. bruises, hæmatomata, etc.; and (2) joint injuries, i.e. sprains.

One hundred consecutive cases of each type were collected, alternate cases being given Varidase Buccal, I tablet (streptokinase 10,000 units/ streptodornase minimum of 2,500 units) q.i.d. for three days. The controls were given no tablets, but local treatment was the same in both treated and untreated cases.

Childrén under I4 years of age and patients with associated bony injury were excluded from the series.

\section{Evaluation of Results}

The criteria used for evaluating the results were the time, in days, to achieve:

(I) Freedom from pain;

(2) Full movements or function of the injured part; and

(3) Disappearance of the bruise or swelling.

The mean of these three figures has been calculated and is called the 'Resolution Index'. Although this term may not be a strictly accurate one, it makes comparison simpler than using the figures of each criterion separately.

Unfortunately nearly half the patients in each series failed to attend for adequate follow-up, an\$ had to be excluded from the series (Table r).

\section{Results}

These are shown graphically in Figs. I and In the joint series the mean of the Resolutionit Index is 12.4 days in the controls and 8.75 däys in those treated. This shows a statistically sig nificant improvement in those receiving Varidase Buccal $(t=2.2,0.05>p>0.02)$.

In the soft tissue series the mean of the Reso lution Index is 9.0 days in the controls an $\vec{\Phi}$ 7.13 days in those treated. Statistically this is only suggestive that the drug produces an im provement $(t=1.68,0.10>p>0.05)$.

However, if this drug produces its effect b dissolving fibrin, its maximum effect will bo within the first few days. If one looks at the number of cases with a Resolution Index of 7 day or less, there is a marked difference between treated cases and controls (Table 2). In the joint series 8 out of $26(30 \%)$ controls compared with I 4 out of $24(58 \%)$ treated patients were ' cured $\frac{7}{0}$ in 7 days or less. In the soft tissue series the corresponding figures are 13 out of $28(46 \%$ controls, and 20 out of $31(64 \%)$ treated.

\section{Discussion}

Although the figures, taken as a whole, may not be very striking there have been a few individuaf cases which have shown impressive results. Thuo 2 cases of 'black eye' subsided completely in 48 hours; 2 cases of sprained ankle had nळ clinically detectable swelling after $I$ and 3 day $\overrightarrow{8}$ 
TABLE I

PERCENTAGE of ATTENDANCES for FOLLOW UP.

\begin{tabular}{|l|c|c|}
\hline & SOFT TISSUES & JOINTS \\
\hline $\begin{array}{l}\text { TREATED WITH } \\
\text { VARIDASE }\end{array}$ & 31 out of $50=62 \%$ & 26 out of $50=52 \%$ \\
\hline CONTROLS & 28 out of $50=56 \%$ & 24 out of $50=48 \%$ \\
\hline
\end{tabular}

TABLE II

PATIENTS with RESOLUTION INDEX of 7 or LESS

\begin{tabular}{|l|c|c|}
\hline & SOFT TISSUES & JOINTS \\
\hline $\begin{array}{l}\text { TREATED WITH } \\
\text { VARIDASE }\end{array}$ & 20 out of $31=64 \%$ & 14 out of $24=58 \%$ \\
\hline CONTROLS & 13 out of $28=46 \%$ & 8 out of $26=30 \%$ \\
\hline
\end{tabular}

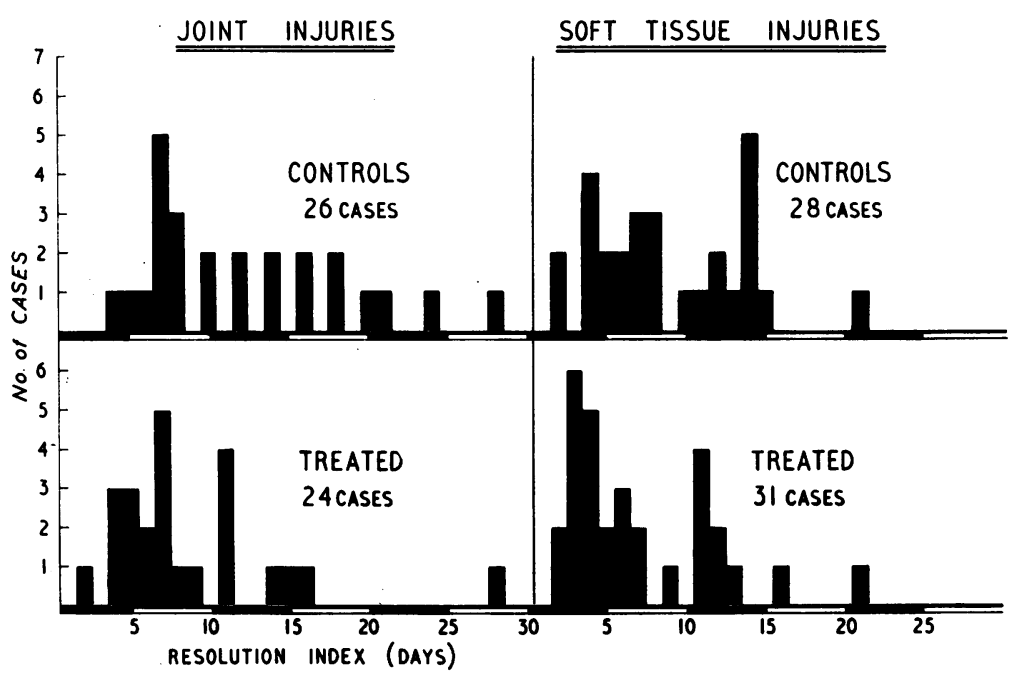

Fig. I.

Fig. 2.

respectively; and 2 cases of finger-joint injuries had no swelling after 3 days and their movements were greatly improved, though. a full pain-free range took longer to achieve.

Conversely, there have been patients who have been remarkable for their lack of response. This may have been due to improper use of the tablets, as the enzyme is inactivated by gastric juices; thus anyone who swallowed the tablets would get no benefit from them.

Our impression is that those who started treatment early got the best results; this is what one would expect from the method of their action.

\section{Summary}

Two series of patients were followed, closed soft tissue injuries and joint sprains. A Resolution Index was used to compare results.

The results showed a definite improvement in those treated in the joint series, and are suggestive that the drug produces speedier resolution in the soft tissue series.

\section{Acknowledgments}

We wish to thank Lederle Laboratories who supplied the drug. We are grateful to Drs. B. Elliott, M. H. Heal, P. H. Setna and J. P. Wilson who helped in the collection and clinical assessment of patients. We also wish to thank Miss Hewland, the medical artist, and the Photographic Department of the Middlesex Hospital who prepared the graphs and tables. 